Goldschmidt 2021 Abstract

https://doi.org/10.7185/gold2021.5062

\section{Chromitites as a memory for the lithosphere origin, evolution and recycling}

\author{
DR. ANASTASSIA Y. BORISOVA ${ }^{1,2}$, NAIL R. \\ ZAGRTDENOV $^{3}$, GEORGES CEULENEER ${ }^{1}$, MICHAEL J. \\ TOPLIS $^{4}$ AND OLEG G. SAFONOV ${ }^{2,5}$
}

${ }^{1}$ Géosciences Environnement Toulouse

${ }^{2}$ Lomonosov Moscow State University

${ }^{3}$ CanmetMINING

${ }^{4}$ Institut de Recherche en Astrophysique et Planétologie

${ }^{5}$ Korzhinskii Institute of Experimental Mineralogy

Presenting Author: anastassia.borisova@get.omp.eu

Chromitites reliably record the whole history of the lithosphere, its origin, evolution and recycling. Crystallization of chromitites containing predominant chromite may be reproduced experimentally by interacting hydrated peridotite with basaltic melt in the presence of hydrous fluid below $1300^{\circ} \mathrm{C}$ at $0.2 \mathrm{GPa}$, i.e. at the conditions expected at the mantle-crust transition beneath the modern oceanic spreading centers [1,2]. Partial melting of the hydrated peridotite in the presence of the basaltic melt is likely responsible for the production of the modern petrologic Moho mantle-crust transition zone at a depth of $\sim 6$ $\mathrm{km}$. The interaction produces dunite-chromitite rocks associated to the felsic melts and aqueous fluids in the mantle and the mantle-crust transition zone. Similar mechanism of the hydrated peridotite-basalt interaction might happen and result in felsic crust formation on early steps of the lithosphere evolution during Hadean and Noachian eons (Fig. 1).

High stability of chromium-rich spinel at high temperature and pressure, up to $1600{ }^{\circ} \mathrm{C}$ and $13-14 \mathrm{GPa}$ is the reason why ultrahigh pressure chromitites may be produced and preserved during oceanic lithosphere recycling to the modern terrestrial mantle [3].

[1] Borisova A.Y. et al. (2020). Hydrated Peridotite - Basaltic Melt Interaction Part II: Serpentinized lithospheric mantle assimilation by oceanic basalts is fast. Front. Earth Sci., doi: 10.3389/feart.2020.00084.

[2] Borisova A.Y. et al. (2021). Hydrated Peridotite - Basaltic Melt Interaction Part I: Planetary felsic crust formation at shallow depth. Front. Earth Sci., doi: $10.3389 /$ feart.2021.640464.

[3] Akaogi M. et al. (2018). High-pressure phase transitions in $\mathrm{MgCr}_{2} \mathrm{O}_{4} \cdot \mathrm{Mg}_{2} \mathrm{SiO}_{4}$ composition: Reactions between olivine and chromite with implications for ultrahigh-pressure chromitites. Am. Mineral. 103, 161-170.

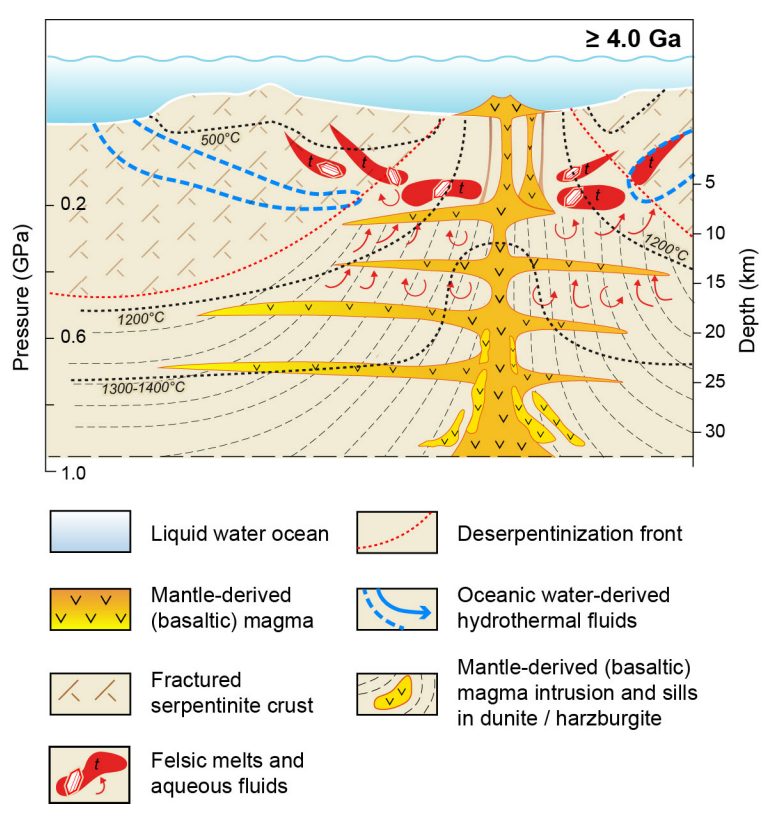

